\title{
Food restriction decreases BMR, body and organ mass, and cellular energetics, in the Chinese Bulbul (Pycnonotus sinensis)
}

(a) CrossMark

Yiying Zhang ${ }^{1 \dagger}$, Ke Yang $^{1 \dagger}$, Peipei Yang ${ }^{1}$, Yingshi Su${ }^{1}$, Weihong Zheng ${ }^{1,2^{*}}$ and Jinsong Liu ${ }^{1} 2^{*}$

\begin{abstract}
Background: Food is an important environmental factor that affects animals' energy metabolism and food shortage has significant effects on animals' behavior, physiology and biochemistry. However, to date few studies have focused on the thermogenesis and its effects on the body condition of birds. In this study, we examined the effects of food restriction on the body mass, basal metabolic rate (BMR) and body composition, and several physiological, biochemical and molecular markers potentially related to thermogenesis, in the Chinese Bulbul (Pycnonotus sinensis).
\end{abstract}

Methods: Birds in the control group were provided with food ad libitum whereas those in the food restriction group were provided with one-half of the usual quantity of food for 12 days. Oxygen consumption was measured using an open-circuit respirometry system. Mitochondrial state 4 respiration and cytochrome c oxidase (COX) activity in the liver and pectoral muscle were measured with a Clark electrode. Avian uncoupling protein (avUCP) mRNA expression was determined in pectorals muscle with quantitative Real-time PCR.

Results: Chinese Bulbuls in food restriction group decreased in body mass, BMR and internal organ (heart, kidneys, small intestine and total digestive tract) mass compared with the control group over the 12-day period of food restriction. Bulbuls in the food restriction group also had lower levels of state-4 respiration, COX activity in the liver and muscle, and mitochondrial avUCP gene expression in muscle compared to the control group. BMR was positively correlated with body mass, state 4 respiration in the liver and COX activity in the muscle.

Conclusions: Our data indicate that Chinese Bulbuls not only sustain food shortage through simple passive mechanisms, such as reducing body and organ mass and energy expenditure, but also by reducing energetic metabolism in the liver and muscle.

Keywords: Avian uncoupling protein, Basal metabolic rate, Cytochrome c oxidase, Food restriction, Pycnonotus sinensis, State-4 respiration

\section{Background}

Phenotypic flexibility allows individual organisms to match phenotypes to environmental or ecological demands (Piersma and Drent 2003; Nussey et al. 2005; Swanson et al. 2014). Flexibility of physiological phenotypes within individuals can be expected when environmental demands vary over time as a result of ontogeny,

\footnotetext{
*Correspondence: zwh@wzu.edu.cn; ljs@wzu.edu.cn

${ }^{+}$Yiying Zhang and Ke Yang contributed equally to this work ${ }^{1}$ School of Life and Environmental Sciences, Wenzhou University, Wenzhou's Chashan University Town, Wenzhou 325035, China Full list of author information is available at the end of the article
}

shifting environmental regimes (e.g., winter cold or food shortage), or behavioral decisions (e.g., to reproduce or migrate) (Diamond and Hammond 1992). Food is an important factor affecting animals' energy metabolism; food resource and quality, as well as animals' assimilative capacity, have a major effect on metabolic rate (Brzęk and Konarzewski 2001; Killpack and Karasov 2012).

The life history of many animals includes extended periods of food scarcity (Hiebert 1991; Foster 1997). In birds, different strategies for coping with food shortage have been described, including torpor (Ruf and Geiser 2014), food hoarding (Garamszegi and Eens 2004), and 
seasonal migration (Pierce and McWilliams 2004). Winter acclimatization and seasonal migration in small birds living in cold climates produce a phenotype characterized by up-regulation of metabolic rate to meet enhanced thermoregulatory demands (Swanson 2010). Decreased food availability, shortened day length for foraging, and increased energy demands due to decreased ambient temperature, indicate that winter is an energetically challenging time for homoeothermic animals (Doucette and Geiser 2008; Liknes and Swanson 2011; Swanson et al. 2014). Although residency and migration are different life-history strategies, they are unified by the common physiological necessity for elevated aerobic capacity and endurance in response to elevated energy expenditure during certain periods of the annual cycle (Dawson et al. 1983; Swanson 2010). It has been demonstrated that a bird's body mass and composition (Kelly and Weathers 2002), energy balance (Liang et al. 2015), basal metabolic rate (BMR) (AL-Mansour 2004; McKechnie and Wolf 2004; Gutiérrez et al. 2011), and reproduction (Perrins 1965; Robb et al. 2008) are all affected by food restriction. Such changes include changes in both physiology and metabolism (Marjoniemi 2000). In laboratory animals, food and calorie restriction have been found to have many beneficial effects (Harper et al. 2006). However, such beneficial effects are at least partially lost when studying wild, or wild-derived, animals. Very few studies have focused on calorie restriction in birds (Ottinger et al. 2005). For example, adaptive and active decreases in energy expenditure in response to food shortage can be pronounced; for example some trochilifromes and galliformes can reduce their metabolic rate by $30-40 \%$ in thermoneutral conditions, eventually entering torpor (Hainsworth et al. 1977; Prinzinger and Siedle 1988). Liang et al. (2015) found when food is limited, birds consume energy reserves, reducing body mass, body fat and organ mass in order to maintain essential metabolic functions. They also reduce energy consumption by reducing their basal metabolic thermogenesis. Birds also use food as a cue for the onset of breeding and food availability can constrain females' ability to produce eggs (Perrins 1965; Boutin 1990). In addition, food restriction may attenuate mitochondrial bioenergetics and oxidative stress in the striped hamster (Cricetulus barabensis) (Zhang et al. 2016). Therefore, substantial efforts have been made to examine the effects of food restriction on animal survival, adaptation, and reproductive success (Prinzinger and Siedle 1988; Robb et al. 2008).

BMR (basal metabolic rate) in small birds is an example of a flexible trait that can be seasonally modulated through adjustments at several levels of organization (McKechnie 2008; Swanson 2010). At the organ level, changes in the mass of metabolically active organs can influence BMR (Daan et al. 1990; Williams and Tieleman 2000; Liu and Li 2006; Zheng et al. 2008a, 2014a). Internal organs (i.e., the liver, kidney, heart, and digestive tract) represent less than $10 \%$ of body mass, but contribute more than $60 \%$ of energy expenditure (Clapham 2012). At the biochemical level, variation in cellular catabolic enzyme activities and/or capacity for metabolic substrate transport in the liver and muscle is often measured by examining variation in state-4 respiration (reflecting oxidative phosphorylation capacity), the activity of citrate synthase (CS; a key regulatory enzyme of the Krebs cycle) or cytochrome c oxidase (COX; a key regulatory enzyme of oxidative phosphorylation) (Vézina and Williams 2005; Swanson 2010). In addition to these morphological and physiological adjustments, molecular regulation might also contribute to variation in thermogenesis in birds (Bicudo et al. 2001; Dridi et al. 2004). Uncoupling proteins (UCPs), located in the inner membrane of mitochondria, have the potential to dissipate free energy as heat by uncoupling oxidative phosphorylation (Ricquier and Bouillaud 2000). UCP1, the first uncoupling protein, is expressed exclusively in brown adipose tissue (BAT), which is critical for protection against the cold in rodents (Cannon and Nedergaard 2004), and has been implicated in regulating both thermogenesis and energy balance (Ricquier and Bouillaud 2000). In recent years, uncoupling protein gene homologues have been cloned and sequenced from chicken skeletal muscle, avian uncoupling protein (avUCP) (Raimbault et al. 2001; Rey et al. 2010; Teulier et al. 2010) and hummingbird (HmUCP) (Vianna et al. 2001), and are thought to play a key role in facultative thermogenesis in birds in response to cold, mainly through non-shivering thermogenesis (NST). However, recent evidence suggests that the primary role of avUCP is regulating oxidative balance rather than thermoregulation (Talbot et al. 2004; Mozo et al. 2005; Teulier et al. 2010).

The Chinese Bulbul (Pycnonotus sinensis) is a small passerine with a wide geographical range that includes vast areas of central, southern, and eastern China, as well as other parts of eastern and southern Asia, including regions with cold winters (MacKinnon and Phillipps 2000). It is common in Zhejiang Province and has recently spread to central China. Within its natural range, the Chinese Bulbul prefers scrub lands, bamboo and coniferous forest, but also lives around villages on deforested plains and hills (Zheng and Zhang 2002). The Chinese Bulbul is omnivorous, feeding mainly on arthropods (e.g., insects and spiders) and mollusks (e.g., snails and slugs) in spring and summer and plant foods (e.g., buds, fruits and seeds) in autumn and winter (Peng et al. 2008). Elevated winter BMR in bulbuls is associated with elevated nutritional and exercise organ mass and 
heightened respiratory enzyme activity in the liver and muscle (Zhang et al. 2008; Zheng et al. 2008a, b, 2010). Decreased BMR in bulbuls is associated with decreased nutritional and exercise organ mass during periods of food shortage (Liang et al. 2015). With global warming, Chinese Bulbuls have recently spread to northern China-a region with less food in winter, but a similar average temperature to the pre-global warming temperature in southern China (Zheng et al. 2010). Bulbuls are non-migratory and must therefore have greater capacity to adjust their energetic expenditure and thermogenesis in response to seasonal changes in temperature and food availability than migratory birds. It is therefore of interest to examine the features underlying this flexibility.

In this study, we used an integrative approach to measure changes in thermogenic properties of Chinese Bulbuls during food restriction at different levels of biological organization from the physiological to molecular, including BMR, nutritional and exercise organ mass, mitochondrial state- 4 respiration and COX activity in the liver and muscle, and avUCP mRNA expression in muscle. More specifically, we test the hypothesis that bulbuls adjust to food restriction by decreasing their body mass and the mass of various internal organs, and by reducing their BMR, state- 4 respiration, COX activity and avUCP mRNA content.

\section{Materials and methods}

\section{Bird capture and acclimation}

This study was carried out in Wenzhou City, Zhejiang Province $\left(27^{\circ} 29 \mathrm{~N}, 120^{\circ} 51^{\mathrm{E}} \mathrm{E}, 14 \mathrm{~m}\right.$ in elevation), China. The climate is warm-temperate with an average annual rainfall of $1500 \mathrm{~mm}$ spread across all months with slightly more precipitation during spring and summer. Mean daily temperatures range from $28-39{ }^{\circ} \mathrm{C}$ in July to $3-8{ }^{\circ} \mathrm{C}$ in January (Zheng et al. 2008b, 2014a).

Adult Chinese Bulbuls were captured by mist nets in Wenzhou City in October 2012, then transported to the laboratory and maintained in individual enclosures $(60 \mathrm{~cm} \times 60 \mathrm{~cm} \times 30 \mathrm{~cm})$ at $25 \pm 1{ }^{\circ} \mathrm{C}$ on a $12: 12-\mathrm{h}$ light-dark photoperiod with lights on at 06:00 a.m. Food (commercial bulbul pellets: $20 \%$ crude protein, $6 \%$ crude fat, $4 \%$ crude fiber, $1 \%$ calcium; Xietong Bioengineering, Jiangsu, China) and water were supplied ad libitum (Zheng et al. 2013a). Chinese Bulbuls showed significant seasonal variation in body mass; birds were $21 \%$ heavier in winter than summer (Zheng et al. 2014a). Birds were kept under these conditions for 2 weeks, then randomly assigned to one of two groups; a control group $(n=12)$, which had access to food ad libitum, and a food restriction group (FR) $(n=10)$, which was provided with onehalf of the usual quantity of food for 12 days (Karasov et al. 2004). All experimental procedures were approved by the Wenzhou City Animal Care and Use Committee.

\section{Measures of metabolic rate}

Oxygen consumption was measured using an opencircuit respirometry system (S-3A/I, AEI technologies, Pittsburgh, PA, USA) (Zheng et al. 2014a; Wu et al. 2015). The metabolic chambers were $1.5 \mathrm{~L}$ in volume and contained a perch for birds to stand on (Smit and McKechnie 2010). Individual birds were allowed to rest in a metabolic chamber which was housed in a temperature-controlled cabinet capable of regulating temperature to $\pm 0.5^{\circ} \mathrm{C}$ (Artificial Climatic Engine BIC-300, Shanghai, China). Air was scrubbed of $\mathrm{H}_{2} \mathrm{O}$ and $\mathrm{CO}_{2}$ by passing it through a silica gel/soda lime/silica column, before and after passing through the metabolic chamber. The fractional concentrations of oxygen in excurrent gas were measured from the metabolic chamber with an oxygen sensor (AEI Technologies N-22 M, USA). The pump was located downstream of the metabolic chamber and air was pulled through the chamber at $300 \mathrm{~mL} /$ min by the pump during metabolic rate measurements. This maintained a fractional concentration of $\mathrm{O}_{2}$ in the respirometry chamber of about $20 \%$, calibrated to $\pm 1 \%$ accuracy with a general purpose thermal mass flowmeter (TSI 4100 Series, USA) (McNab 2006). Oxygen consumption rates were measured at $25 \pm 0.5{ }^{\circ} \mathrm{C}$, which is within the thermal neutral zone of the Chinese Bulbul (Zheng et al. 2008b, 2014a). Baseline $\mathrm{O}_{2}$ concentrations were obtained before and after each test ( $\mathrm{Li}$ et al. 2010; Wu et al. 2015). All gas exchange measurements were obtained during the rest-phase of birds' circadian cycles (between 20:00 and 04:00) in dark chambers. Food was removed $4 \mathrm{~h}$ before each test to create post-absorptive conditions. Measurement of oxygen consumption commenced when birds were observed perching calmly in the chamber and continued for $1 \mathrm{~h}$. Each animal was generally in the metabolic chamber for at least $2 \mathrm{~h}$. From these data, we calculated 5 min running means of steady-state oxygen consumption over the entire test period using equation 2 of Hill (1972) and considered the lowest 5 min mean oxygen consumption recorded over the test period as the resting metabolic rate (Wu et al. 2015). Metabolic rates were expressed as $\mathrm{mL} \mathrm{O}_{2} / \mathrm{h}$ and corrected to STPD conditions. Body mass was measured to the nearest $0.1 \mathrm{~g}$ before and after experiments; mean body mass was used in calculations.

\section{Measurement of organ mass and fat content}

Birds were killed by decapitation after metabolic measurements were completed and their pectoral muscle, brain, heart, lungs, liver, kidneys, gizzard, small intestine, and rectum removed and weighed to $\pm 0.1 \mathrm{mg}$. 
Sub-samples of liver and muscle were used for preparation of mitochondria (Zheng et al. 2008a, 2014b). Internal organs, including the remaining portions of the liver and muscle, were dried to a constant mass over $2 \mathrm{~d}$ at $65{ }^{\circ} \mathrm{C}$ and weighed to $\pm 0.1 \mathrm{mg}$ (Williams and Tieleman 2000; Zhang et al. 2008). The remainder of the carcass was then weighed to determine its wet mass, then dried in an oven at $65{ }^{\circ} \mathrm{C}$ to a constant mass and then reweighed (to $\pm 0.1 \mathrm{mg}$ ) to determine its dry mass (Liu and Li 2006; Zheng et al. 2008a). Total fat was extracted from the dried carcasses by ether extraction in a Soxtec 2050 Soxhlet apparatus (FOSS Instrument, Germany). Body and liver fat content was calculated according to Dawson et al. (1983) and Wu et al. (2014) as follows:

$$
\begin{aligned}
& \text { Body fat content }(\%) \\
& \quad=(\text { total fat of carcass } / \text { wet carcass mass }) \times 100 \% \\
& \text { Liver fat content }(\%) \\
& \quad=(\text { total fat of liver } / \text { wet liver mass }) \times 100 \%
\end{aligned}
$$

\section{Preparation of mitochondria}

Liver and pectoral muscle sub-samples were cleaned of any adhering tissue, blotted dry, and weighed before being placed in ice-cold sucrose-buffered medium. Both liver and pectoral muscle samples were then coarsely chopped with scissors, after which liver samples were rinsed and resuspended in $5 \mathrm{vol}$ of ice-cold medium ( $250 \mathrm{mmol} / \mathrm{L}$ sucrose, $5 \mathrm{mmol} / \mathrm{L}$ Tris/ $\mathrm{HCl}, 1 \mathrm{mmol} / \mathrm{L}$ $\mathrm{MgCl}_{2}$ and $0.5 \mathrm{mmol} / \mathrm{L}$ EDTA, $\mathrm{pH} \mathrm{7.4,}{ }^{\circ} \mathrm{C}$ ) (Rasmussen et al. 2004). Pectoral muscle samples were treated with proteinase for 5-10 min, then resuspended in $10 \mathrm{vol}$ of ice-cold medium $(100 \mathrm{mmol} / \mathrm{L} \mathrm{KCl}, 50 \mathrm{mmol} / \mathrm{L}$ Tris/HCl, $5 \mathrm{mmol} / \mathrm{L} \mathrm{MgSO}_{4}$ and $1 \mathrm{mmol} / \mathrm{L}$ EDTA, $\mathrm{pH} 7.4,4{ }^{\circ} \mathrm{C}$ ). Liver and muscle preparations were then homogenized in a Teflon/glass homogenizer. Homogenates were centrifuged at $600 \mathrm{~g}$ for $10 \mathrm{~min}$ at $4{ }^{\circ} \mathrm{C}$ in an Eppendorf centrifuge after which the resultant pellets of nuclei and cell debris was discarded. The supernatants were then centrifuged at $12,000 \mathrm{~g}$ for $10 \mathrm{~min}$ at $4{ }^{\circ} \mathrm{C}$. The resultant pellets were suspended, respun at $12,000 \mathrm{~g}$, resuspended, and the final pellets $(2: 1, \mathrm{w} / \mathrm{v}$ for liver and $4: 1$ for muscle) placed in ice-cold medium (Zheng et al. 2013b; Zhou et al. 2016). The protein content of mitochondria was determined by the Folin phenol method with bovine serum albumin as standard (Lowry et al. 1951).

\section{Mitochondrial respiration and enzyme activity}

We measured mitochondrial state- 4 respiration in liver and pectoral muscle at $30{ }^{\circ} \mathrm{C}$ in $1.96 \mathrm{~mL}$ of respiration medium (225 mmol/L sucrose, $50 \mathrm{mmol} / \mathrm{L}$ Tris/ $\mathrm{HCl}, 5 \mathrm{mmol} / \mathrm{L} \mathrm{MgCl}_{2}, 1 \mathrm{mmol} / \mathrm{L}$ EDTA and $5 \mathrm{mmol} / \mathrm{L}$ $\mathrm{KH}_{2} \mathrm{PO}_{4}, \mathrm{pH}$ 7.4) with a Clark electrode (Hansatech
Instruments LTD., England, DW-1), essentially as described by Estabrook (1967). State-4 respiration and cytochrome $c$ oxidase (COX) activity were measured in both muscle and liver tissue. State- 4 respiration was measured over a $1 \mathrm{~h}$ period under substrate dependent conditions, with succinate as the substrate (Zheng et al. 2013b, 2014a). COX activity was measured polarographically at $30^{\circ} \mathrm{C}$ using a Clark electrode as described in Sundin et al. (1987). We express state-4 respiration and COX activity measurements as mass-specific $\left[\mu \mathrm{mol} \mathrm{O}_{2} /(\mathrm{min} \mathrm{g}\right.$ tissue)], measurements (Wiesinger et al. 1989; Zheng et al. 2013b, 2014b).

\section{Avian uncoupling protein mRNA expression}

Avian uncoupling protein (avUCP) mRNA expression was determined in pectoral muscle by quantitative Realtime PCR (RT-qPCR). Total RNA was isolated from bulbul pectorals muscle as described by Chomczynski and Sacchi (1987) using the E.Z.N.A Total RNA Extraction Kit (R6834-02, Omega). The integrity of the RNA obtained was tested using agarose electrophoresis and the RNA concentration was estimated with a Micro-Ultraviolet Spectrophotometer (NanoDrop 2000c, Thermo Scientific). A Reverse Transcription System (A3500, Promega) was used to manufacture cDNA samples with total RNA as the template. A $10 \mu \mathrm{L}$ RT mixture of each sample $(1 \mu \mathrm{g}$ total RNA) was prepared using $2 \mu \mathrm{L}$ of $10 \times$ Buffer, $4 \mu \mathrm{L}$ of $\mathrm{MgCl}_{2}(25 \mathrm{mmol} / \mathrm{L}), 2 \mu \mathrm{L} \mathrm{dNTP} \mathrm{Mixture}(10 \mathrm{mmol} / \mathrm{L})$, $0.5 \mu \mathrm{L}$ Recombinant RNasin ${ }^{\circledR}$ Ribonuclease Inhibitor, 15 $\mathrm{U}$ of AMV Reverse Transcriptase (High Conc.), $0.5 \mu \mathrm{L}$ of Oligo (dT) (15 Primer) and nuclease-free water to a final volume of $20 \mu \mathrm{L}$. Specific primers were designed based on the cDNA sequence of the Chinese Bulbul listed in GenBank (Accession No. JQ353836). The avUCP primers

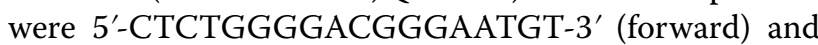
5'-AGGAAGGACGGGACGAAG-3' (reverse). The reference primer $\beta$-actin was made essentially as described by Rey et al. (2008). The reaction began with an initial denaturation for $5 \mathrm{~min}$ at $95^{\circ} \mathrm{C}$ followed by 40 cycles of denaturation at $94{ }^{\circ} \mathrm{C}$ for $30 \mathrm{~s}$, annealing at $60^{\circ} \mathrm{C}$ for $15 \mathrm{~s}$, and extension at $72{ }^{\circ} \mathrm{C}$ for $30 \mathrm{~s}$.

\section{Data analysis}

Data were analyzed using SPSS (version 19.0). The normality of all variables was examined with the Kolmogorov-Smirnov test and non-normally distributed data were $\log _{10}$ transformed. The significance of betweengroup differences were evaluated with an independent sample $t$ test. In order to correct for the effect of body mass, analysis of covariance (ANCOVA) was used to analyze between-group differences in organ mass, using body mass minus wet organ mass as a covariate for the organ in question to avoid part-whole correlations 
(Christians 1999). Partial and residual correlations were used to evaluate the relationship between BMR and dry organ mass, and least-squares linear regression to evaluate the relationships between $\log B M R$ and log body mass, $\log$ state- 4 respiration, $\log$ COX and $\log$ avUCP. $p$ values $<0.05$ were considered statistically significant.

\section{Results}

\section{Body mass and basal metabolic rate (BMR)}

No between-group differences in body mass $\left(t_{20}=\right.$ $0.299, p=0.704)$ or BMR $\left(t_{20}=0.904, p=0.377\right)$ were found prior to food restriction. However, birds in the FR group underwent a significant decrease in body mass $\left(t_{20}=4.838, p<0.0001\right.$; Fig. $\left.1 \mathrm{a}\right)$ and BMR $\left(t_{20}=2.292, p\right.$ $=0.033$; Fig. 1b), relative to those in the control group. A significant, positive correlation was found between body mass and $\operatorname{BMR}\left(R^{2}=0.201, p=0.036\right.$; Fig. 1c).

\section{Body composition}

The FR group had significantly lower body fat $\left(t_{20}=\right.$ 4.631, $p<0.0001)$ and liver fat $\left(t_{20}=12.484, p<0.0001\right)$ compared to the control group after 12 days of food restriction (Fig. 2a). The mass of the heart, kidneys, small intestine and total digestive tract was also significantly lower in the FR group than in the control group (Table 1). There was a positive correlation between body mass and body fat $\left(R^{2}=0.491\right.$, $p<0.0001$; Fig. 2b), and between body mass and liver fat $\left(R^{2}=0.408, p=0.001\right.$; Fig. 2 c). Partial correlation analysis indicated significant, positive correlations between BMR and dry heart mass and between BMR and dry kidney mass (Table 2).

\section{Mitochondrial respiration and cytochrome $\mathrm{C}$ oxidase (COX) activity}

The FR group had significantly decreased levels of state-4 respiration in the liver $\left(t_{20}=2.132, p=0.045\right)$ and muscle $\left(t_{20}=3.180, p=0.007\right)$ (Fig. 3a), and decreased COX activity in the liver $\left(t_{20}=2.828\right.$, $p=0.010)$ and muscle $\left(t_{20}=4.554, p<0.0001\right)$ (Fig. 3b), compared to the control group. BMR was positively correlated with and state-4 respiration in the liver (Fig. 4a), and with COX activity in muscle (Fig. 4d).

\section{Avian uncoupling protein (avUCP) mRNA level}

The FR group had significantly lower avUCP $\left(t_{11}=3.293\right.$, $p=0.007$ ) than the control group (Fig. 5).
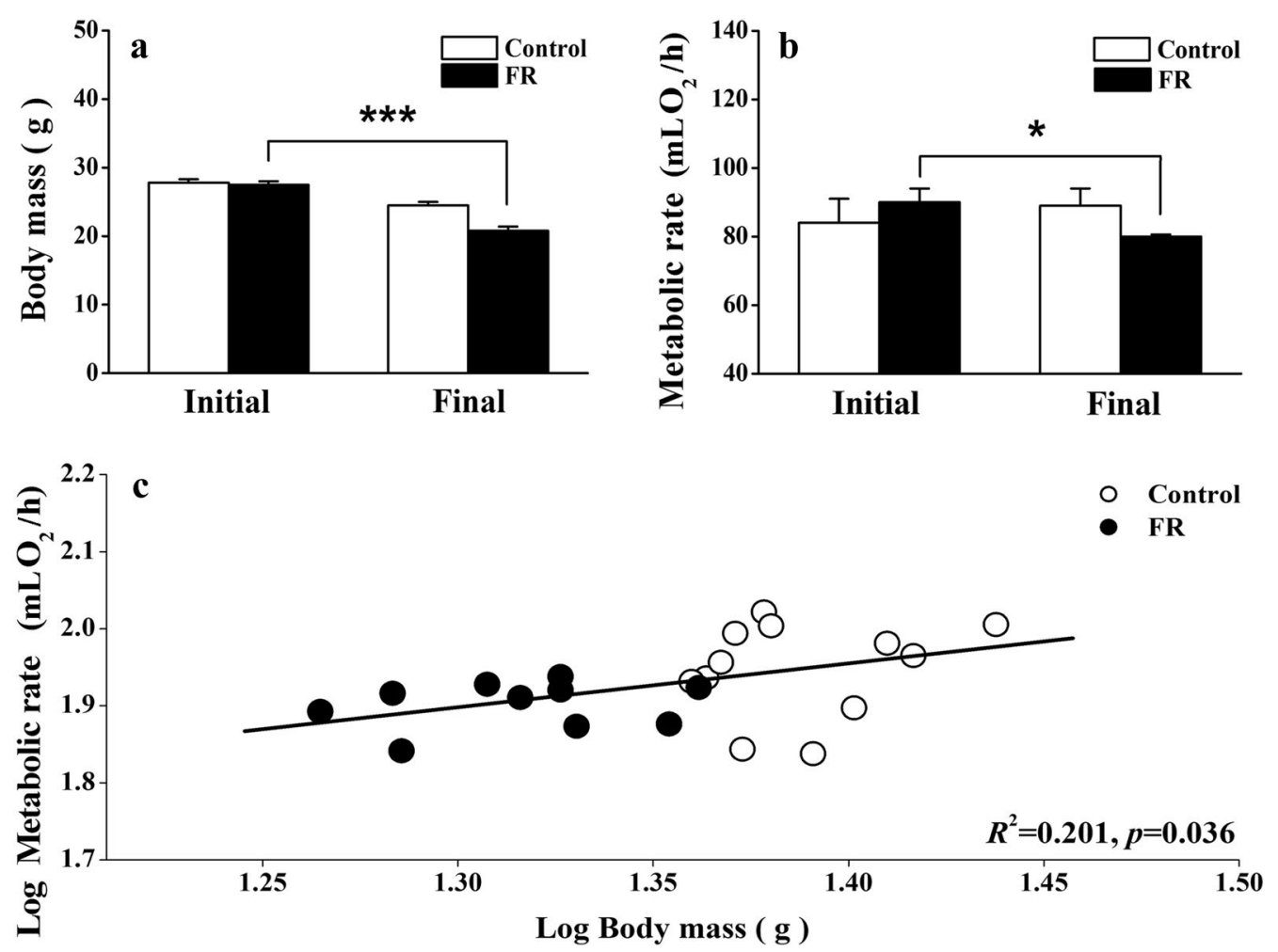

Fig. 1 Comparison of body mass (a), basal metabolic rate (b), and the relationship between body mass and basal metabolic rate (c), between Chinese Bulbuls (Pycnonotus sinensis) that were provided with food ad libitum (control group) and those that were provided with half the usual quantity of food (food restriction group), after 12 days. Data are shown as mean $\pm S E M,{ }^{*} p<0.05,{ }^{* * *} p<0.001$. FR food restriction group 

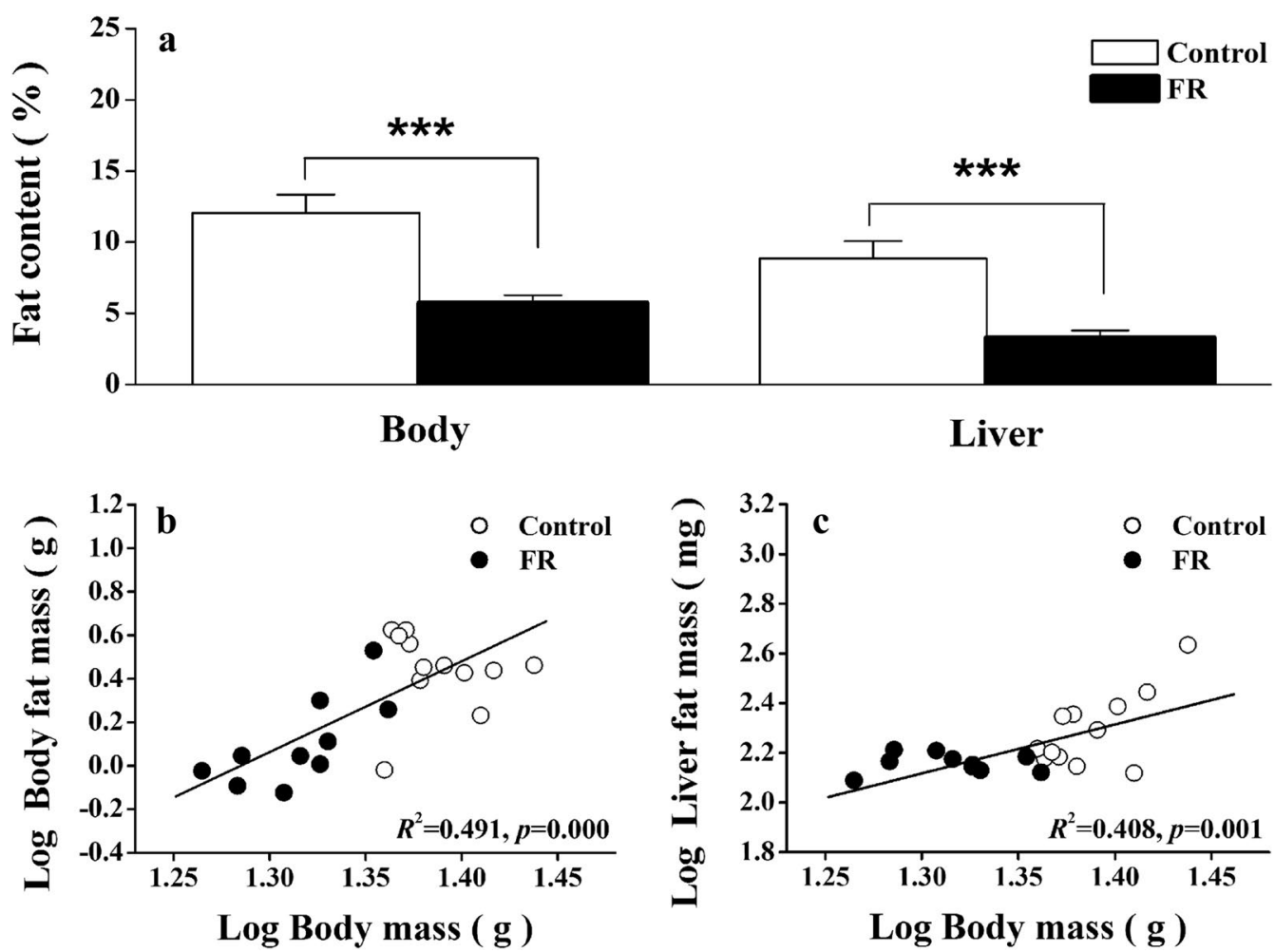

Fig. 2 Comparison of body and liver fat content (a), the relationship between body mass and body fat mass (b), and the relationship between body mass and liver fat mass (c), between Chinese Bulbuls (Pycnonotus sinensis) that were provided with food ad libitum (control group) and those that were provided with half the usual quantity of food (food restriction group), after 12 days. Data are shown as mean \pm SEM, ${ }^{* * *} p<0.001$. FR food restriction group

Table 1 Dry mass of various internal organs (controlled for body mass minus wet organ mass) of Chinese Bulbuls (Pycnonotus sinensis) after 12 days food restriction

\begin{tabular}{llll}
\hline & Control & FR & Significance \\
\hline Sample size (n) & 12 & 10 & \\
Muscle (mg) & $297.0 \pm 22.3$ & $220.0 \pm 25.4$ & $F_{1,19}=3.585, p=0.074$ \\
Brain (mg) & $187.5 \pm 10.4$ & $203.0 \pm 11.9$ & $F_{1,19}=0.664, p=0.425$ \\
Heart (mg) & $75.4 \pm 5.3$ & $58.3 \pm 6.1$ & $F_{1,19}=4.504, p=0.047$ \\
Lung (mg) & $57.0 \pm 3.6$ & $53.9 \pm 4.2$ & $F_{1,19}=0.217, p=0.646$ \\
Liver (mg) & $66.0 \pm 9.6$ & $84.7 \pm 10.9$ & $F_{1,19}=1.143, p=0.298$ \\
Kidney (mg) & $86.4 \pm 4.5$ & $71.6 \pm 5.2$ & $F_{1,19}=4.418, p=0.048$ \\
Gizzard (mg) & $102.2 \pm 10.6$ & $92.1 \pm 12.1$ & $F_{1,19}=0.269, p=0.610$ \\
Small intestine (mg) & $242.3 \pm 22.3$ & $158.6 \pm 25.5$ & $F_{1,19}=7.081, p=0.015$ \\
Rectum (mg) & $15.9 \pm 4.5$ & $19.4 \pm 5.2$ & $F_{1,19}=0.182, p=0.674$ \\
Digestive tract (mg) & $371.5 \pm 30.6$ & $269.9 \pm 34.9$ & $F_{1,19}=5.005, p=0.037$ \\
\hline
\end{tabular}

Data are presented as mean \pm SEM

FR food restriction

\section{Discussion}

Food limitation has been shown to affect a wide variety of morphological, physiological, and behavioral functions in animals (Kelly and Weathers 2002; McKechnie and Wolf 2004; Gutiérrez et al. 2011). We found that 12 days of food restriction decreased the body mass, body fat, energy expenditure, internal organ (kidney, heart and small intestine) mass, and BMR, of Chinese Bulbuls, and also decreased state- 4 respiration and COX activity in their liver and muscle mitochondria. Food restriction also caused a decrease in avUCP in muscle.

\section{Effects of food restriction on the morphology} and physiology of Chinese Bulbuls

Birds, like many other animals, rarely have unlimited access to food in the wild and consequently have evolved the ability to drastically change their morphology and physiology in response to food shortage (Piersma and Lindstrom 1997; Klaassen et al. 2004). Chinese Bulbuls responded to food restriction by decreasing their body mass, BMR and altering their body composition. Body mass is an important index that reflects an animal's nutritional status (Kelly and Weathers 2002) and its stability depends on the balance between energy intake and expenditure (Hegemann et al. 2012). Our results show 
Table 2 Partial, and residual, correlations between basal metabolic rate and the dry mass of various organs (controlled for body mass minus wet organ mass) of Chinese Bulbuls (Pycnonotus sinensis) after 12 days food restriction

\begin{tabular}{|c|c|c|c|c|c|c|c|c|c|c|}
\hline & Muscle & Brain & Heart & Lung & Liver & Kidney & Gizzard & Small intestine & Rectum & Digestive tract \\
\hline \multicolumn{11}{|c|}{ Partial correlations } \\
\hline$R^{2}$ & 0.182 & 0.006 & 0.318 & 0.123 & 0.138 & 0.321 & 0.333 & 0.049 & 0.080 & 0.045 \\
\hline$p$ & 0.047 & 0.730 & 0.006 & 0.109 & 0.089 & 0.006 & 0.096 & 0.321 & 0.204 & 0.346 \\
\hline \multicolumn{11}{|c|}{ Residual correlations } \\
\hline$R^{2}$ & 0.040 & 0.007 & 0.129 & 0.011 & 0.001 & 0.135 & 0.3146 & 0.052 & 0.008 & 0.023 \\
\hline$p$ & 0.369 & 0.973 & 0.100 & 0.649 & 0.845 & 0.092 & 0.806 & 0.304 & 0.694 & 0.505 \\
\hline
\end{tabular}

$p$ values in italics are statistically significant

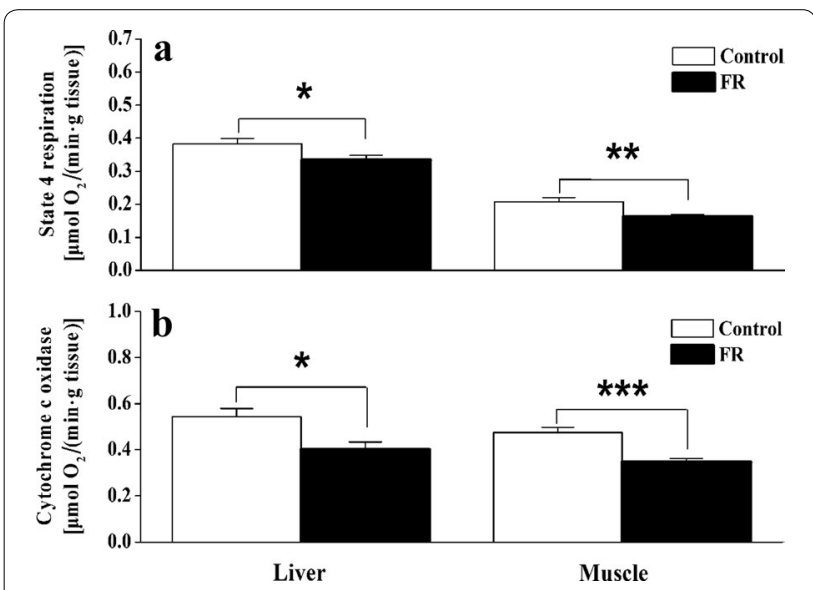

Fig. 3 Differences in state-4-respiration (a) and cytochrome C oxidase (b) in the liver and pectoral muscle of Chinese Bulbuls (Pycnonotus sinensis) that were provided with food ad libitum (control group) and those provided with half of the usual quantity of food (food restriction group group), after 12 days. Data are shown as mean \pm SEM, ${ }^{*} p<0.05,{ }^{* *} p<0.01,{ }^{* * *} p<0.001$. FR food restriction group

that 12 days of food restriction was sufficient to cause Chinese Bulbuls to undergo a significant decrease in body mass of $13 \%$. Such a reduction in body mass generally reduces maintenance requirements thereby resulting in a decrease in whole-body energy expenditure. Similar results have been found in Eurasian Tree Sparrows (Passer montanus) (Yang et al. 2010) and White Throated Sparrows (Zonotrichia albicollis) (Pierce and McWilliams 2004). Fat reserves can supply emergency energy reserves during periods of food shortage (O'Connor 1995; Guglielmo and Williams 2003). Increased fat levels in the body and liver in winter, or during migration, are common in many temperate passerines, enabling these birds to meet increased thermoregulatory demands and provide a nutritional buffer against temporary foraging restrictions caused by inclement weather (Dawson and Marsh 1986; Swanson 1991a). Our data show that Chinese Bulbuls in the FR group had lower body and liver fat compared to the control group. The FR birds may have had to consume their fat reserves to compensate for their decreased energy intake (Swanson 1991b; Cooper 2007; Liknes et al. 2014). FR birds also had a lighter heart, kidneys, small intestine and digestive tract than control birds. This suggests that food deprivation has a profound effect on the body composition and digestive organs of birds. Furthermore, our results are consistent with those of previous studies (Liang et al. 2015) in showing that food restriction induces a significant reduction in the BMR of Chinese Bulbuls. These results suggest that the ability to decrease their BMR is an important adaptation used by Bulbuls to survive periods of food shortage. Several authors have suggested that much of the energy used in basal metabolism is consumed by visceral organs (Daan et al. 1990; Piersma and Lindstrom 1997), including the small intestine (storage, digestion and absorption), the heart and lungs (oxygen transport), the liver (catabolism), and the kidneys (waste elimination) (Daan et al. 1990; Li et al. 2017). Although the liver, kidney, heart, and digestive tract comprise less than $10 \%$ of total body mass, they consume $50-70 \%$ of total energy expenditure (Rolfe and Brown 1997; Clapham 2012). We found that the mass of the heart, kidneys, small intestine and digestive tract decreased significantly in FR bulbuls, compared to those in the control group, which suggests that bulbuls reduce the mass of these organs when food is limited to decrease their energy expenditure and thereby ultimately their metabolic rate.

\section{Biochemical responses to food restriction in liver and muscle}

The liver is one of the largest and most metabolically active organs in birds and can also contribute to the thermogenesis (Villarin et al. 2003; Dumas et al. 2004; Zheng et al. 2008a, b). Under basal metabolic conditions, the liver has been shown to contribute $25 \%$ of total heat production (Li et al. 2001; Zheng et al. 2008b). Skeletal muscles have lower mass-specific metabolic rates, but due to their total mass, contribute significantly to seasonal acclimatization through their role in thermogenesis (Scott 

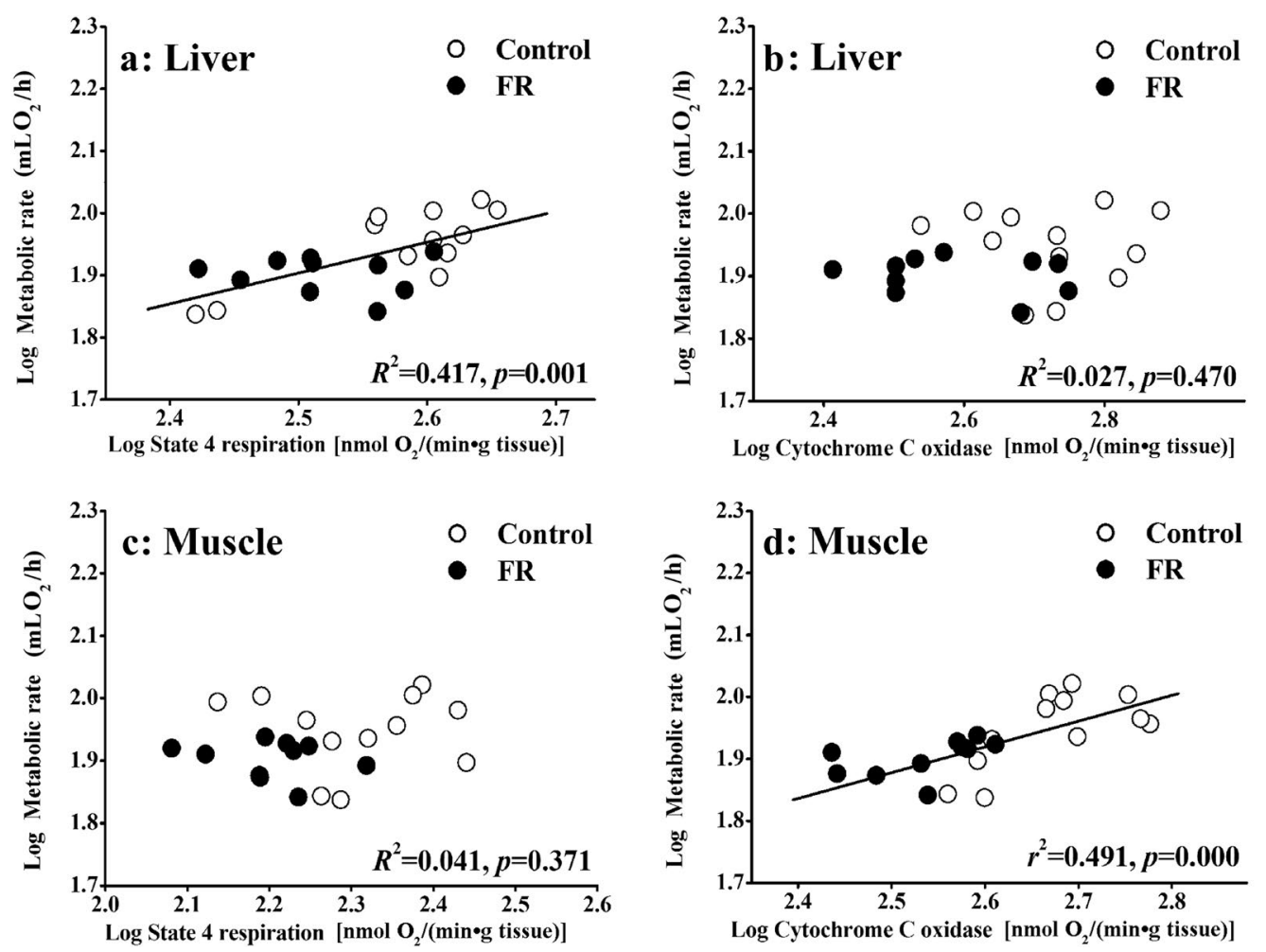

Fig. 4 Correlations between basal metabolic rate (BMR), state-4-respiration, and cytochrome $C$ oxidase in the liver, and pectoral muscle, in Chinese Bulbuls (Pycnonotus sinensis) that were provided with food ad libitum (control group) and in those provided with half the usual quantity of food (food restriction group group), over 12 days

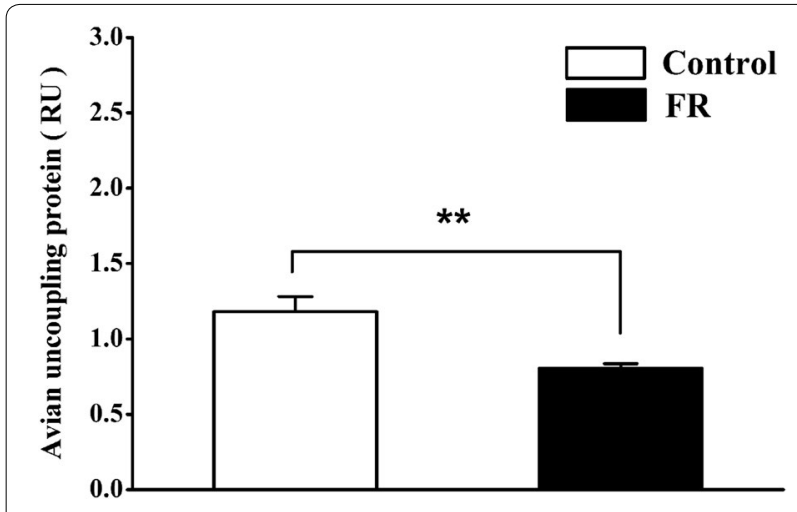

Fig. 5 Differences in levels of avian uncoupling protein in Chinese Bulbuls (Pycnonotus sinensis) that were provided with food ad libitum (control group) and in those provided with half the usual quantity of food (food restriction group group), over 12 days. Data are shown as mean $\pm S E M,{ }^{* *} p<0.01$. FR food restriction group

and Evans 1992; Chappell et al. 1999). Mitochondrial state- 4 respiration, and cytochrome $\mathrm{C}$ oxidase (COX) activity are indicators of cellular metabolic intensity and can reflect metabolic activity in these tissues (Zheng et al. 2008a, 2014a; Swanson 2010; Swanson et al. 2014).
A reduction in metabolic rate should lead to a decrease in the utilization of substrates by tissues and organs (Sartori et al. 1995), a hypothesis supported by the changes in biochemical markers (i.e., mitochondrial protein content, state-4 respiration and COX activity) we observed in Chinese Bulbuls. Our results show that liver mitochondrial protein content, state-4 respiration and COX activity decreased significantly in the FR group compared to the control group. This result is interesting and, since neither liver nor muscle underwent a significant decrease in organ mass (although both did decreased in mass by 19-33\%), suggests that reducing cellular energy consumption may be more important than reducing organ masses. These decreases are consistent with a mechanistic down regulation of intracellular metabolic capacity in response to food restriction, suggesting that this mechanism may be important to bulbuls' ability to respond to changing seasonal energy demands.

Birds do not have brown adipose tissue but have the ability to increase the thermogenic capacity of their skeletal muscles through shivering thermogenesis and adaptive non-shivering processes after cold acclimation (Barré et al. 1986; Dridi et al. 2004; Abe et al. 2006). This may be achieved through change in the specific mitochondrial 
anion carrier avUCP (Dridi et al. 2004). AvUCP mRNA is upregulated in the skeletal muscles of chickens after exposure to cold, which is known to be associated with increased energy expenditure (Toyomizu et al. 2002; Collin et al. 2003; Teulier et al. 2010). However, it is worth noting that the studies relating avUCP to NST in birds were all done on chicks rather than adults (Vianna et al. 2001; Toyomizu et al. 2002; Mozo et al. 2005; Teulier et al. 2010). This suggests that the incomplete muscular development of chicks may reduce their capacity for shivering thermogenesis to the extent that their thermoregulatory demands may need to be supported by NST, whereas adult birds with fully developed shivering capacities may be less reliant on NST. Our results suggest that food restriction induced a significant decrease in the avUCP content of muscle in bulbuls, which is consistent with previous findings in king penguins (Rey et al. 2010). This indicates that rather than thermogenesis or reducing oxidative stress, it is quite possible that the main function of avUCP is to maintain optimized mitochondrial membrane potential (Brand 2000).

\section{Conclusions}

In conclusion, the results of our study demonstrate that Chinese Bulbuls respond to food restriction at the organismal, physiological and molecular levels, including decreasing their body mass and changing their body composition, reducing metabolic thermogenesis, and decreasing enzymatic activity and the amount of mitochondrial anion carrier in specific organs. These morphological, physiological and biochemical responses could be a part of the seasonal acclimatization used by bulbuls to adjust to seasonal changes in food abundance, especially during winter. This phenotypic flexibility may enable the Chinese Bulbul to survive periods of seasonal food limitation (Liang et al. 2015).

\section{Authors' contributions}

WZ and $J L$ designed the study. $Y Z, K Y, P Y$ and $Y S$ performed the work. $Y Z, K Y$, and $Y S$ analyzed the data, and $Y Z, K Y, W Z$ and $J$ wrote the manuscript. All authors participated in revising the manuscript. All authors read and approved the final manuscript.

\section{Author details \\ 1 School of Life and Environmental Sciences, Wenzhou University, Wenzhou's Chashan University Town, Wenzhou 325035, China. ${ }^{2}$ Zhejiang Provincial Key Lab for Water Environment and Marine Biological Resources Protection, Wenzhou 325035, China.}

\section{Acknowledgements}

We thank Dr. Ron Moorhouse revising the English. Thanks to all the members of Animal Physiological Ecology Group, and the Wenzhou University Institute of Applied Ecology, for their helpful suggestions, and the anonymous reviewers for their helpful comments and suggestions on earlier drafts of this manuscript.

\section{Competing interests}

The authors declare that they have no competing interests.
Consent for publication

Not applicable.

\section{Ethics approval and consent to participate}

All experimental procedures were approved by the Animal Care and Use Committee of the Wenzhou University.

\section{Funding}

This study was financially supported by grants from the National Natural Science Foundation of China (No. 31470472), the National Undergraduate "Innovation" Project and the Zhejiang Province 'Xinmiao' Project.

\section{Publisher's Note}

Springer Nature remains neutral with regard to jurisdictional claims in published maps and institutional affiliations.

Received: 22 March 2018 Accepted: 15 November 2018

Published online: 21 November 2018

\section{References}

Abe T, Mujahid A, Sato K, Akiba Y, Toyomizu M. Possible role of avian uncoupling protein in down-regulating mitochondrial superoxide production in skeletal muscle of fasted chickens. FEBS Lett. 2006;580:4815-22.

AL-Mansour MI. Seasonal variation in basal metabolic rate and body composition within individual sanderling bird Calidris alba. J Biol Sci. 2004;4:564-7.

Barré H, Cohen-Adad F, Duchamp C, Rouanet JL. Multilocular adipocytes from muscovy ducklings differentiated in response to cold acclimation. J Physiol. 1986;375:27-38.

Bicudo JEPW, Vianna CR, Chaui-Berlinck JG. Thermogenesis in birds. Biosci Rep. $2001 ; 2: 181-8$

Boutin S. Food supplementation experiments with terrestrial vertebratespatterns, problems, and the future. Can J Zool. 1990;68:203-20.

Brand MD. Uncoupling to survive? The role of mitochondrial inefficiency in ageing. Exp Gerontol. 2000;35:811-20.

Brzęk P, Konarzewski M. Effect of food shortage on the physiology and competitive abilities of sand martin (Riparia riparia) nestlings. J Exp Biol. 2001;204:3065-74.

Cannon B, Nedergaard J. Brown adipose tissue: function and significance. Physiol Rev. 2004;84:227-359.

Chappell MA, Bech C, Buttemer WA. The relationship of central and peripheral organ masses to aerobic performance variation in house sparrows. J Exp Biol. 1999;202:2269-79.

Chomczynski P, Sacchi N. Single-step method of RNA isolation by acid guanidium thiocyanate-phenol-chloroform extraction. Anal Biochem. 1987;162:156-9.

Christians JK. Controlling for body mass effects: is part-whole correlation important? Physiol Biochem Zool. 1999;72:250-3.

Clapham JC. Central control of thermogenesis. Neuropharmacology. 2012;63:111-723.

Collin A, Buyse J, Van As P, Darras VM, Malheiros RD, Moraes VMB, Reyns GE, Taouis M, Decuypere E. Cold-induced enhancement of avian uncoupling protein expression, heat production, and triiodothyronine concentrations in broiler chicks. Gen Comp Endocrinol. 2003;130:70-7.

Cooper SJ. Daily and seasonal variation in body mass and visible fat in mountain chickadees and juniper titmice. Wilson J Ornithol. 2007;119:720-4.

Daan S, Masman D, Groenewold A. Avian basal metabolic rates: their association with body composition and energy expenditure in nature. Am J Physiol. 1990;259:R333-40.

Dawson WR, Marsh RL. Winter fattening in the American Goldfinch and the possible role of temperature in its regulation. Physiol Zool. 1986;59:357-68.

Dawson WR, Marsh RL, Buttemer WA, Carey C. Seasonal and geographic variation of cold resistance in house finches. Physiol Zool. 1983;56:353-69.

Diamond J, Hammond K. The matches, achieved by natural selection, between biological capacities and their natural loads. Experientia. 1992;48:551-70.

Doucette LI, Geiser F. Seasonal variation in thermal energetics of the Australian owlet-nightjar (Aegotheles cristatus). Comp Biochem Physiol A 2008:151:615-20. 
Dridi S, Onagbesan O, Swennen Q, Buyse J, Decuypere E, Taouis M. Gene expression, tissue distribution and potential physiological role of uncoupling protein in avian species. Comp Biochem Physiol A. 2004;139:273-83.

Dumas JF, Roussel D, Simard G, Douay O, Foussard F, Malthiery Y, Ritz P. Food restriction affects energy metabolism in rat liver mitochondria. Biochim Biophys Acta. 2004;1670:126-31.

Estabrook RW. Mitochondrial respiratory control and polarographic measurement of ADP/O ratio. In: Estabrook RW, Pullman ME, editors. Methods in enzymes, X. New York: Academic Press; 1967. p. 41-7.

Foster MS. Ecological and nutritional effects of food scarcity on a tropical frugivorous bird and its fruit source. Ecology. 1997;589:73-85.

Garamszegi LZ, Eens M. The evolution of hippocampus volume and brain size in relation to food hoarding in birds. Ecol Lett. 2004;7:1216-24.

Guglielmo CG, Williams TD. Phenotypic flexibility of body composition in relation to migratory state, age, and sex in the western sandpiper (Calidris mauri). Physiol Biochem Zool. 2003;76:84-98.

Gutiérrez JS, Masero JA, Abad-Gómez JM, Villegas A, Sánchez-Guzmán JM. Metabolic consequences of overlapping food restriction and cell-mediated immune response in a long-distance migratory shorebird, the little ringed plover Charadrius dubius. J Avian Biol. 2011;42:259-65.

Hainsworth FR, Collins BG, Wolf LL. The function of torpor in hummingbirds. Physiol Zool. 1977;50:215-22.

Harper JM, Leather CW, Austad SN. kDoes caloric restriction extend life in wild mice? Aging Cell. 2006;5:441-9.

Hegemann A, Matson KD, Versteegh MA, Tieleman BI. Wild skylarks seasonally modulate energy budgets but maintain energetically costly inflammatory immune responses throughout the annual cycle. PLOS ONE. 2012;7:e36358.

Hiebert SM. Seasonal differences in the response of rufous hummingbirds to food restriction: body mass and the use of torpor. Condor. 1991;93:526-37.

Hill RW. Determination of oxygen consumption by use of the paramagnetic oxygen analyzer. J Appl Physiol. 1972;33:261-3.

Karasov WH, Pinshow B, Starck JM, Afik D. Anatomical and histological changes in the alimentary tract of migrating blackcaps (Sylvia atricapilla): a comparison among fed, fasted, food-restricted, and refed birds. Physiol Biochem Zool. 2004;77:149-60.

Kelly JP, Weathers WW. Effects of feeding time constraints on body mass regulation and energy expenditure in wintering Dunlin (Calidris alpina). Behav Ecol. 2002;13:766-75.

Klaassen M, Oltrogge M, Trost L. Basal metabolic rate, food intake, and body mass in cold- and warm-acclimated garden warblers. Comp Biochem Phys A. 2004;137:639-47.

KillpackTL, Karasov WH. Growth and development of house sparrows (Passer domesticus) in response to chronic food restriction throughout the nestling period. J Exp Biol. 2012;215:1806-15.

Li M, Sun YQ, Mao HZ, Hu JH, Zheng WH, Liu JS. Seasonal phenotypic flexibility in body mass, basal thermogenesis, and tissue oxidative capacity in the male Silky Starling (Sturnus sericeus). Avian Res. 2017;8:25.

Li QF, Sun RY, Huang CX, Wang ZK, Liu XT, Hou JJ, Liu JS, Cai LQ, Li N, Zhang SZ, Wang Y. Cold adaptive thermogenesis in small mammals from different geographical zones of China. Comp Biochem Physiol A. 2001;129:949-61.

Li YG, Yang ZC, Wang DH. Physiological and biochemical basis of basal metabolic rates in Brandt's voles (Lasiopodomys brandtii) and Mongolian gerbils (Meriones unguiculatus). Comp Biochem Physiol A. 2010;157:204-11.

Liang QJ, Zhao L, Wang JQ, Chen Q, Zheng WH, Liu JS. Effect of food restriction on the energy metabolism of the Chinese bulbul (Pycnonotus sinensis). Zool Res. 2015;36:79-87.

Liknes ET, Swanson DL. Phenotypic flexibility of body composition associated with seasonal acclimatization in passerine birds. J Therm Biol. 2011;36:363-70.

Liknes ET, Guglielmo CG, Swanson DL. Phenotypic flexibility in passerine birds: seasonal variation in fuel storage, mobilization and transport. Comp Biochem Physiol A. 2014;174:A1-10.

Liu JS, Li M. Phenotypic flexibility of metabolic rate and organ masses among tree sparrows Passer montanus in seasonal acclimatization. Acta Zool Sin. 2006;52:469-77.

Lowry OH, Rosebrough NJ, Farr AL, Randall R. Protein measurement with Folin phenol reagent J Biol Chem. 1951;193:265-75.
MacKinnon J, Phillipps K. A field guide to the birds of China. London: Oxford University Press; 2000

Marjoniemi K. The effect of short-term fasting on shivering thermogenesis in Japanese quail chicks (Coturnix coturnix japonica): indications for a significant role of diet-induced/growth related thermogenesis. J Therm Biol. 2000;25:459-65.

McKechnie AE. Phenotypic flexibility in basal metabolic rate and the changing view of avian physiological diversity: a review. J Comp Physiol B. 2008:178:235-47.

McKechnie AE, Wolf BO. The allometry of avian basal metabolic rate: good predictions need good data. Physiol Biochem Zool. 2004;77:502-21.

McNab BK. The relationship among flow rate, chamber volume and calculated rate of metabolism in vertebrate respirometry. Comp Biochem Physiol A. 2006;145:287-94.

Mozo J, Emre Y, Bouillaud F, Ricquier D, Criscuolo F. Thermoregulation: what role for UCPs in mammals and birds? Biosci Rep. 2005;25:227-49.

Nussey DH, Postma E, Gienapp P, Visser ME. Selection on heritable phenotypic plasticity in a wild bird population. Science. 2005;310:304-6.

O'Connor TP. Metabolic characteristics and body composition in House Finches: effects of seasonal acclimatization. J Comp Physiol B. 1995; 165:298-305.

Ottinger MA, Mobarak M, Abdelnabi M, Roth G, Proudman J, Ingram DK. Effects of calorie restriction on reproductive and adrenal systems in Japanese quail: are responses similar to mammals, particularly primates? Comp Biochem Physiol A. 2005;126:967-75.

Peng HY, Wen QH, Huang J, Huang Y. The study of spring diet habit of three species of Pycnonotidae. Sichuan J Zool. 2008;27:99-101.

Perrins CM. Population fluctuations and clutch-size in the great tit Parus major L. J Anim Ecol. 1965;34:601-47.

Pierce BJ, McWilliams SR. Diet quality and food limitation affect the dynamics of body composition and digestive organs in a migratory songbird (Zonotrichia albicollis). Physiol Biochem Zool. 2004;77:471-83.

Piersma T, Lindstrom Å. Rapid reversible changes in organ size as a component of adaptive behavior. Trends Ecol Evol. 1997;12:134-8.

Piersma T, Drent J. Phenotypic flexibility and the evolution of organismal design. Trends Ecol Evol. 2003;18:228-33.

Prinzinger R. Siedle K. Ontogeny of metabolism, thermoregulation and torpor in the house martin Delichon u. urbica (L.) and its ecological significance. Oecologia. 1988;76:307-12.

Raimbault S, Dridi S, Denjean F, Lachuer J, Couplan E, Bouillaud F, Bordas A, Duchamp C, Taouis M, Ricquier D. An uncoupling protein homologue putatively involved in facultative muscle thermogenesis in birds. Biochem J. 2001;353:441-4.

Rasmussen UF, Vielwerth SE, Rasmussen V. Skeletal muscle bioenergetics: a comparative study of mitochondria isolated from pigeon pectoralis, rat soleus, rat biceps brachii, pig biceps femoris and human quadriceps. Comp Biochem Physiol A. 2004;137:435-46.

Rey B, Halsey LG, Dolmazon V, Rouanet J-L, Roussel D, Handrich Y, Butter PJ, Duchamp C. Long-term fasting decreases mitochondrial avian UCPmediated oxygen consumption in hypometabolic king penguins. Am J Physiol. 2008;295:R92-100.

Rey B, Roussel D, Romestaing C, Belouze M, Rouanet J-L, Desplanches D, Sibille $B$, Servais S, Ducham C. Up-regulation of avian uncoupling protein in cold-acclimated and hyperthyroid ducklings prevents reactive oxygen species production by skeletal muscle mitochondria. BMC Physiol. 2010;10:5.

Ricquier D, Bouillaud F. The uncoupling protein homologues: UCP1, UCP2, UCP3, StUCP and AtUCP. Biochem J. 2000;345:161-79.

Robb GN, McDonald RA, Chamberlain DE, Reynolds SJ, Harrison TJE, Bearhop S. Winter feeding of birds increases productivity in the subsequent breeding season. Biol Lett. 2008;4:220-3.

Rolfe DF, Brown GC. Cellular energy utilization and molecular origin of standard metabolic rate in mammals. Physiol Rev. 1997;77:731-58.

RufT, Geiser F. Daily torpor and hibernation in birds and mammals. Biol Rev. 2014;90:891-926.

Sartori DR, Migliorini RH, Veiga JA, Moura JL, Kettelhut IC, Linder C. Metabolic adaptations induced by long-term fasting in quails. Comp Biochem Physiol A. 1995;111:487-93.

Scott I, Evans PR. The metabolic output of avian (Sturnus vulgaris, Calidris alpina) adipose tissue, liver and skeletal muscle: implications for BMR/ body mass relationships. Comp Biochem Physiol A. 1992;103:329-32. 
Smit B, McKechnie AE. Avian seasonal metabolic variation in a subtropical desert: basal metabolic rates are lower in winter than in summer. Funct Ecol. 2010;24:330-9.

Sundin U, Moore G, Nedergaard J, Cannon B. Thermogenin amount and activity in hamster brown fat mitochondria: effect of cold acclimation. Am J Physiol. 1987;252:R822-32.

Swanson DL. Seasonal adjustments in metabolism and insulation in the darkeyed junco. Condor. 1991a;93:538-45.

Swanson DL. Substrate metabolism under cold stress in seasonally acclimatized dark-eyed juncos. Physiol Zool. 1991b;64:1578-92.

Swanson DL. Seasonal metabolic variation in birds: functional and mechanistic correlates. In: Thompson CF, editor. Current ornithology. Berlin: Springer; 2010. p. 75-129.

Swanson DL, Zhang Y, Liu JS, Merkord CL, King MO. Relative roles of temperature and photoperiod as drivers of metabolic flexibility in dark-eyed juncos. J Exp Biol. 2014;217:866-75.

Talbot DA, Duchamp C, Rey B, Hanuise N, Rouanet JL, Sibille B, Brand MD. Uncoupling protein and ATP/ADP carrier increase mitochondrial proton conductance after cold adaptation of king penguins. J Physiol. 2004:558:123-35.

Teulier L, Rouanet J-L, Letexier D, Romestaing C, Belouze M, Rey B, Duchamp C, Roussel D. Cold-acclimation-induced non-shivering thermogenesis in birds is associated with upregulation of avian UCP but not with innate uncoupling or altered ATP efficiency. J Exp Biol. 2010;213:2476-82.

Toyomizu M, Ueda M, Sato S, Seki Y, Sato K, Akiba Y. Cold-induced mitochondrial uncoupling and expression of chicken UCP and ANT mRNA in chicken skeletal muscle. FEBS Lett. 2002;529:313-8.

Vézina F, Williams TD. Interaction between organ mass and citrate synthase activity as an indicator of tissue maximal oxidative capacity in breeding European starlings: implications for metabolic rate and organ mass relationships. Funct Ecol. 2005:19:119-28.

Vianna CR, Hagen T, Zhang CY, Bochman E, Boss O, Gereben B, Moriscot AS, Lowell BB, Bicudo JEPW, Bianco AC. Cloning and functional characterization of an uncoupling protein homolog in hummingbirds. Physiol Genom. 2001;5:137-45.

Villarin JJ, Schaeffer PJ, Markle RA, Lindstedt SL. Chronic cold exposure increases liver oxidative capacity in the marsupial Monodelphis domestica. Comp Biochem Physiol A. 2003;136:621-30.

Wiesinger $\mathrm{H}$, Heldmaier $\mathrm{G}$, Buchberger A. Effect of photoperiod and acclimation temperature on nonshivering thermogenesis and GDP-binding of brown fat mitochondria in the Djungarian hamster Phodopus s. sungorus. Pflugers Arch Eur J Physiol. 1989:413:667-72.

Williams J, Tieleman BI. Flexibility in basal metabolic rate and evaporative water loss among hoopoe larks exposed to different environmental temperatures. J Exp Biol. 2000;203:3153-9.
Wu MS, Xiao YC, Yang F, Zhou LM, Zheng WH, Liu JS. Seasonal variation in body mass and energy budget in Chinese bulbuls (Pycnonotus sinensis). Avian Res. 2014:5:4.

Wu MX, Zhou LM, Zhao LD, Zhao ZJ, Zheng WH, Liu JS. Seasonal variation in body mass, body temperature and thermogenesis in the Hwamei, Garrulax canorus. Comp Biochem Physiol A. 2015;179:113-9.

Yang ZH, Liu JS, Shao SL. The effect of short-term continuing food restriction on Passer montanus body weight and BMR and Its ecological meaning. Chin J Zool. 2010:45:119-24.

Zhang GK, Fang YY, Jiang XH, Liu JS, Zhang YP. Adaptive plasticity in metabolic rate and organ masses among Pycnonotus sinensis in seasonal acclimatization. Chin J Zool. 2008:43:13-9.

Zhang JY, Zhao XY, Wang GY, Wang CM, Zhao ZJ. Food restriction attenuates oxidative stress in brown adipose tissue of striped hamsters acclimated to a warm temperature. J Therm Biol. 2016;58:72-9.

Zheng GM, Zhang CZ. Birds in China. Beijing: China Forestry Publishing House; 2002.

Zheng WH, Li M, Liu JS, Shao SL. Seasonal acclimatization of metabolism in Eurasian tree sparrows (Passer montanus). Comp Biochem Physiol A. 2008a;151:519-25.

Zheng WH, Liu JS, Jang XH, Fang YY, Zhang GK. Seasonal variation on metabolism and thermoregulation in Chinese bulbul. J Therm Biol. 2008b;33:315-9.

Zheng WH, Fang YY, Jang XH, Zhang GK, Liu JS. Comparison of thermogenic character of liver and muscle in Chinese bulbul Pycnonotus sinensis between summer and winter. Zool Res. 2010;31:319-27.

Zheng WH, Lin L, Liu JS, Pan H, Cao MT, Hu YL. Physiological and biochemical thermoregulatory responses of Chinese bulbuls Pycnonotus sinensis to warm temperature: phenotypic flexibility in a small passerine. J Therm Biol. 2013a;38:483-90.

Zheng WH, Lin L, Liu JS, Xu XJ, Li M. Geographic variation in basal thermogenesis in little buntings: relationship to cellular thermogenesis and thyroid hormone concentrations. Comp Biochem Physiol A. 2013b;164:240-6.

Zheng WH, Liu JS, Swanson DL. Seasonal phenotypic flexibility of body mass, organ masses, and tissue oxidative capacity and their relationship to RMR in Chinese bulbuls. Physiol Biochem Zool. 2014a;87:432-44.

Zheng WH, Li M, Liu JS, Shao SL, Xu XJ. Seasonal variation of metabolic thermogenesis in Eurasian tree sparrows Passer montanus over a latitudinal gradient. Physiol Biochem Zool. 2014b;87:704-18.

Zhou LM, Xia SS, Chen Q, Wang RM, Zheng WH, Liu JS. Phenotypic flexibility of thermogenesis in the Hwamei (Garrulax canorus): responses to cold acclimation. Am J Physiol. 2016:310:R330-6.
Ready to submit your research? Choose BMC and benefit from:

- fast, convenient online submission

- thorough peer review by experienced researchers in your field

- rapid publication on acceptance

- support for research data, including large and complex data types

- gold Open Access which fosters wider collaboration and increased citations

- maximum visibility for your research: over $100 \mathrm{M}$ website views per year

At BMC, research is always in progress.

Learn more biomedcentral.com/submissions 